\title{
WSPÓŁPRACA DUŻYCH PRZEDSIĘBIORSTW Z MSP W RAMACH DZIAŁALNOŚCI WDROŻENIOWEJ INNOWACJI
}

DOI: 10.33141/po.2020.01.06

\section{Grzegorz Szymański}

\section{Wprowadzenie}

$\mathbf{P}$ ojęcie innowacji jest coraz częściej powiązywane z rozwojem działalności gospodarczej, a utożsamiane $\mathrm{z}$ nowoczesnością. Współcześnie, aby firma mogła utrzymać wysoką pozycję na rynku, wskazane jest wdrażanie systemów kreowania innowacji w zakresie zarówno optymalizacji procesów produkcyjnych, organizacji, jak i wzrostu konkurencyjności. Problematyka innowacji wśród MSP jest bardzo aktualnym i permanentnie rozwianym obszarem nauki i praktyki gospodarczej (Zastępowski, 2018, s. 7). Dynamiczny postęp technologiczny oraz powszechna globalizacja i cyfryzacja działalności gospodarczej, stopniowa integracja rynków oraz ciągła ewolucja potrzeb i pragnień konsumentów to nowe wyzwania dla współczesnych organizacji, które coraz częściej dążą do wdrażania innowacji. Innowacja w szerokim znaczeniu definiowana jest jako każda zmiana polegająca na przyswajaniu uzyskanej wiedzy, zaś w wąskim znaczeniu określa zmianę $\mathrm{w}$ metodach wytwarzania i produktach (ewentualnie $\mathrm{w}$ organizacji procesu produkcyjnego), bazującą na nowej lub wykorzystanej dotychczas wiedzy (Schumpeter, 1960, s. 104). Analogicznie ogólną definicję przyjmuje Ph. Kotler, który pod pojęciem innowacji określa wszelkie wyniki inwencji i pracy ludzkiej w postaci idei, usługi lub rzeczy uważanej przez odbiorcę za nową, gdzie kluczowym aspektem jest postrzeganie innowacji przez konsumenta (Kotler, 1994, s. 222). Natomiast na potrzeby niniejszej publikacji oraz badania przyjęto, za podręcznikiem Oslo Manual, że innowacja to wprowadzenie do praktyki w przedsiębiorstwie nowego lub znacząco ulepszonego rozwiązania w odniesieniu do produktu (towaru lub usługi), procesu, marketingu lub organizacji (OECD, 2005, s. 10-25).

W analizie konkurencyjności oraz innowacyjności gospodarki rozróżnia się sektor MSP oraz duże ${ }^{1}$ podmioty. Mikro-, małe i średnie przedsiębiorstwa (MSP) odgrywają istotną rolę w kształtowaniu rozwoju gospodarczego, stabilności oraz tworzeniu miejsc pracy (Fritsch, Storey, 2014, s. 952-953). Jednak studium literatury z obszaru rozwoju innowacyjnego i innowacyjności nie potwierdza, że wielkość przedsiębiorstwa, mierzona najczęściej liczbą pracowników, odzwierciedla większą innowacyjność (Forsman, Rantanen, 2011, s. 28). Już Ch. Freeman (1986, s. 123) uważał, że skuteczność innowacyjna MSP może być większa od dużych, gdyż małe podmioty mogą wytwarzać więcej innowacji na jednostkę wydatków na
B+R. Być może dlatego obecny stan badań, na płaszczyźnie innowacji, skupia się na sektorze MSP, który stanowi zdecydowanie liczniejszą grupę podmiotów, pozostawiając obszar dużych przedsiębiorstw mniej przebadany. Przedsiębiorstwa chętniej także korzystają $\mathrm{z}$ innowacji technologicznych niż organizacyjnych, procesowych lub marketingowych (Blażlak, Pomykalski, 2015, s. 15).

Współpraca sektora MSP z innymi podmiotami, w kontekście rozwoju innowacyjnego, ma kluczowe znaczenie dla końcowego sukcesu. Dyrektorzy najwyższego szczebla przedsiębiorstw UE uważają, że większe są szanse na odniesienie sukcesu w innowacjach w przypadku podjęcia współpracy biznesowej. Wśród najistotniejszych motywów do nawiązywania współpracy wskazuje się: dostęp do nowej technologii (89\%), wejście na nowy rynek $(88 \%)$, poprawę rentowności istniejącej oferty $(85 \%)$ oraz poprawę istniejących towarów i usług (85\%) (Mazur-Wierzbicka, 2015, s. 104). Współpraca daje podmiotom gospodarczym dodatkowe kompetencje i większe szanse powodzenia działań innowacyjnych (Ritter i in., 2002, s. 119-138). Mimo iż innowacje traktowane są jako istotne elementy rozwoju współczesnych przedsiębiorstw, to wiele badań dotyczących polskich firm wskazuje, iż ostatnio pojawił się zastój innowacyjny, który spowodował pogorszenie pozycji Polski na światowej scenie innowacji. Nawet przypływ funduszy strukturalnych UE w latach 2007-2013 nie wpłynął pozytywnie na obecny stan polskich innowacji (Jasiński, 2018, s. 238). Mimo iż odnotowano niewielką poprawę w obszarze innowacyjności polskiej gospodarki w ciągu lat 2015-2016, to jej ogólny stan jest wciąż relatywnie niski (Kisielnicki, 2016, s. 77). Od lat najistotniejszym czynnikiem utrudniającym działalność innowacyjną w naszym kraju jest brak wystarczających środków finansowych. W badaniach 63\% przedsiębiorstw wskazało na ważność tego hamulca innowacyjności (Wiśniewska, Janasz, 2018, s. 148).

Przedsiębiorstwo innowacyjne zarządza całym procesem innowacji, w którym wyróżnia się trzy zasadnicze elementy: kreowanie nowego pomysłu, wdrożenie oraz finansowanie. Klasyczny model innowacji obejmuje proces zaczynający się od badań podstawowych, stosowanych, następnie prac rozwojowych, po których następuje wdrożenie i dyfuzja innowacji na rynku (Pomykalski, 1997, s. 73). Trudno stwierdzić, który z tych etapów jest najważniejszy, niemniej jednak wszystkie stanowią kluczowe składniki 
końcowego sukcesu innowacji. Istnienie wielu modeli innowacji, w tym coraz popularniejszego otwartego modelu, determinuje różne zachowania biznesowe (Skrzypek, 2018, s. 102-106). Współcześnie zauważono także istnienie nierozerwalnego związku między kreatywnością a innowacyjnością, bowiem obie biorą udział w procesie twórczym. Kreatywność uruchamia ten proces, natomiast innowacyjność jest jego efektem (Sopińska, 2018, s. 25). Faza wdrażania jest jedną z bardziej kosztownych, gdyż na tym etapie występuje masowa produkcja oraz intensywne działania marketingowe. Ponadto wciąż brak informacji o zaakceptowaniu innowacji przez klientów, co zdecydowanie zwiększa ryzyko inwestycji i utrudnia pozyskanie finansowania zewnętrznego. Decyzja o wdrożeniu innowacji przez przedsiębiorstwo powinna być poprzedzona przeprowadzeniem wielu szacunków i badań, w tym dotyczących wielkości zasobów potrzebnych do realizacji przedsięwzięcia i oczekiwanych korzyści, wynikających z wdrożenia (Kłopotek, 2005, s. 87). Działania wdrożeniowe według literatury i praktyki gospodarczej wskazują, że ten etap stanowi najsłabsze ogniwo procesu innowacyjnego (Jagoda-Sobalak i in., 2017, s. 160), dlatego zdecydowano się na analizę tego zjawiska. Celem niniejszego opracowania jest identyfikacja determinant współpracy dużych przedsiębiorstw z sektorem MSP w obszarze działalności wdrożeniowej innowacji w Polsce. Należy zaznaczyć, iż determinanty mają różny charakter i mogą być rozpatrywane $\mathrm{z}$ wielu różnych punktów widzenia, w niniejszym opracowaniu analiza dotyczy trzech wybranych aspektów, uwzględnionych w pytaniach badawczych, które to obszary zostały wybrane jako istotne $\mathrm{w}$ literaturze przedmiotu (Szymański, Stanisławski 2018, s. 249; Poznańska, 2016, s. 152). Postawione pytania badawcze: jakie jest znaczenie, dla dużych przedsiębiorstw, poszczególnych (wybranych przez autora na podstawie przeglądu literatury) motywów podjęcia współpracy? jakie są największe osiągnięte korzyści dla dużych przedsiębiorstw ze współpracy z MSP oraz które bariery uznano za największe przy współpracy $\mathrm{z}$ MSP $\mathrm{w}$ procesie wdrażania innowacji?

\section{Metoda badawcza}

B adaniu poddano 33 duże przedsiębiorstwa, mające lokalizację na terenie Polski, reprezentujące województwa: łódzkie, mazowieckie, śląskie, wielkopolskie oraz dolnośląskie i warmińsko-mazurskie. Identyfikacja wielkości badanych przedsiębiorstw została określona w oparciu o założenia definicji rozporządzenia Komisji Europejskiej, obowiązującej w Unii Europejskiej (Załącznik nr 1 do Rozporządzenia Komisji Europejskiej), przy czym jako jedyne kryterium przyjęto średnioroczną wielkość zatrudnienia na poziomie 250 i więcej pracowników.

Operat badawczy obejmował przedsiębiorstwa, które w ciągu ostatnich trzech lat współpracowały z MSP w obszarze działalności innowacyjnej, co zostało zweryfikowane $\mathrm{w}$ pytaniu filtrującym. Przy mechanizmie doboru próby wykorzystano wielostopniowy schemat losowania, na który składały się dwa etapy. Pierwszy z nich polegał na doborze celowym przedsiębiorstw prowadzących działalność innowacyjną $\mathrm{w}$ ciągu ostatnich trzech lat. Drugi zaś posiadał charakter losowy, gdzie za pomocą losowania wyłoniono próbę 33 podmiotów. Badania przeprowadzone zostały $\mathrm{z}$ wykorzystaniem dwóch technik badawczych, tj. CATI i CAWI, z których zasadniczą była technika pierwsza (ok. 70\% badania). Do badania CATI i CAWI wykorzystano profesjonalną firmę badawczą, w której zakresie i obowiązkach było odpowiednie przeszkolenie ankieterów odnośnie do badanej problematyki i podstawowych pojęć. Narzędziem badawczym był kwestionariusz ankietowy wykorzystujący pytania zamknięte obowiązkowe. Analizowane wyniki oraz przedstawione wykresy zawierają średnią wartość w skali od 1 do 5 , gdzie 1 oznaczało najmniejsze, zaś 5 największe znaczenie, dla dużych przedsiębiorstw, poszczególnych czynników.

\section{Wybrane determinanty współpracy wdrożeniowej innowacji - wyniki badań}

dentyfikacja czynników wpływających na chęć podejmowania wspólnych działań pomiędzy przedsiębiorstwami została przeprowadzona $\mathrm{w}$ oparciu o studia literaturowe z zakresu rozwoju innowacyjnego (Sudolska, 2009, s. 229; Ratajczak-Mrozek, 2011, s. 207; Stanisławski, 2014, s. 180) oraz praktykę gospodarczą. Wśród zaproponowanych dziewięciu najpopularniejszych determinant podejmowania współpracy między przedsiębiorstwami w obszarze wdrażania innowacji zdecydowanie największe znaczenie dla respondentów ma stworzenie nowych produktów (rys. 1). Proces projektowania i wdrażania na rynek nowych produktów ma na celu zaspokojenie jawnych i ukrytych potrzeb klienta oraz zwiększenie konkurencyjności przedsiębiorstwa. Współpraca $z$ innymi jednostkami pozwala na przyspieszenie i skrócenie całego procesu rozwoju innowacji, a także zmniejszenie kosztów i ryzyka niepowodzenia. Wśród wielu korzyści wynikających $\mathrm{z}$ wprowadzenia nowego produktu na rynek jest obszar zachowań konsumentów, którzy bardzo często wiążą swoje odczucia z marką, która jako pierwsza na rynku zaoferowała im atrakcyjną ofertę. W skrajnym przypadku klienci używają marki jako synonimu nazwy przedmiotu, co stanowi jedną z najbardziej skutecznych form reklamy innowacji. Przykładem może być Adidas, powszechnie używana nazwa jako synonim obuwia sportowego, Pampers - jednorazowych pieluch oraz wiele innych: Xero, Polaroid i Ratrak.

Analizując dalsze wyniki badania, należy podkreślić, że respondenci wskazali na stosunkowo duże znaczenie (rys. 1) dla każdego z analizowanych czynników, co potwierdza coraz większe zainteresowanie współpracą proinnowacyjną oraz prawidłowość identyfikacji czynników motywacyjnych.

Pozytywnym aspektem analizy wyników badania jest także wniosek, iż sama chęć przystąpienia do programów unijnych wsparcia innowacji stanowi najmniej istotny element zwiększający zainteresowanie współpracą. Wśród innych znaczących motywacji należy wskazać: promocję produktów lub marki, realizację wspólnych projektów oraz rozszerzenie własnych rynków zbytu. 


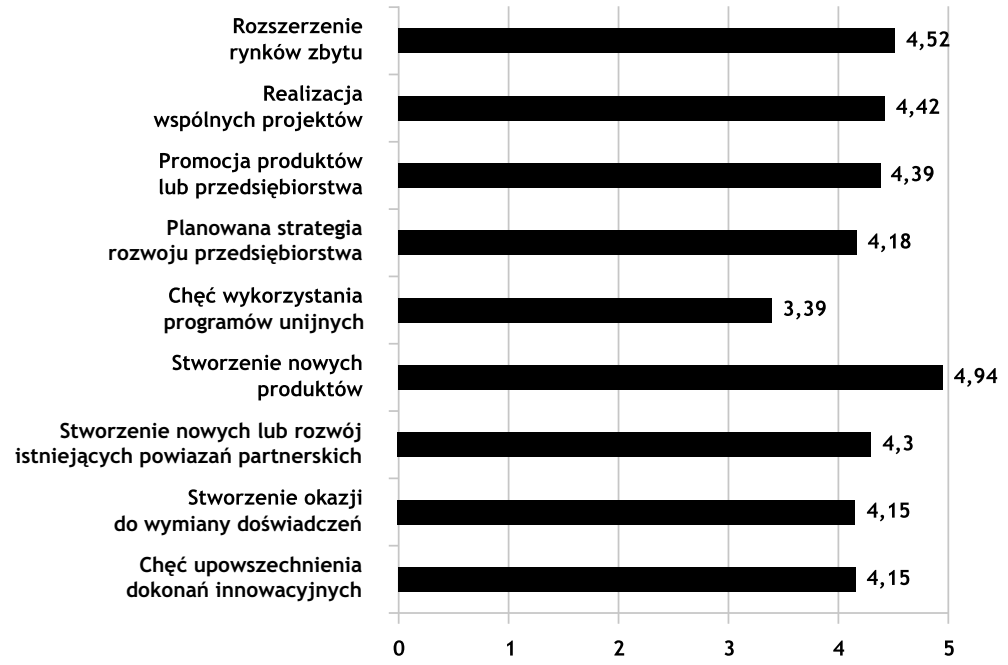

Rys. 1. Znaczenie poszczególnych motywów podjęcia wspótpracy dużych przedsiębiorstw z MSP - wartość średnia, $\mathrm{n}=33$ Źródło: opracowanie wtasne

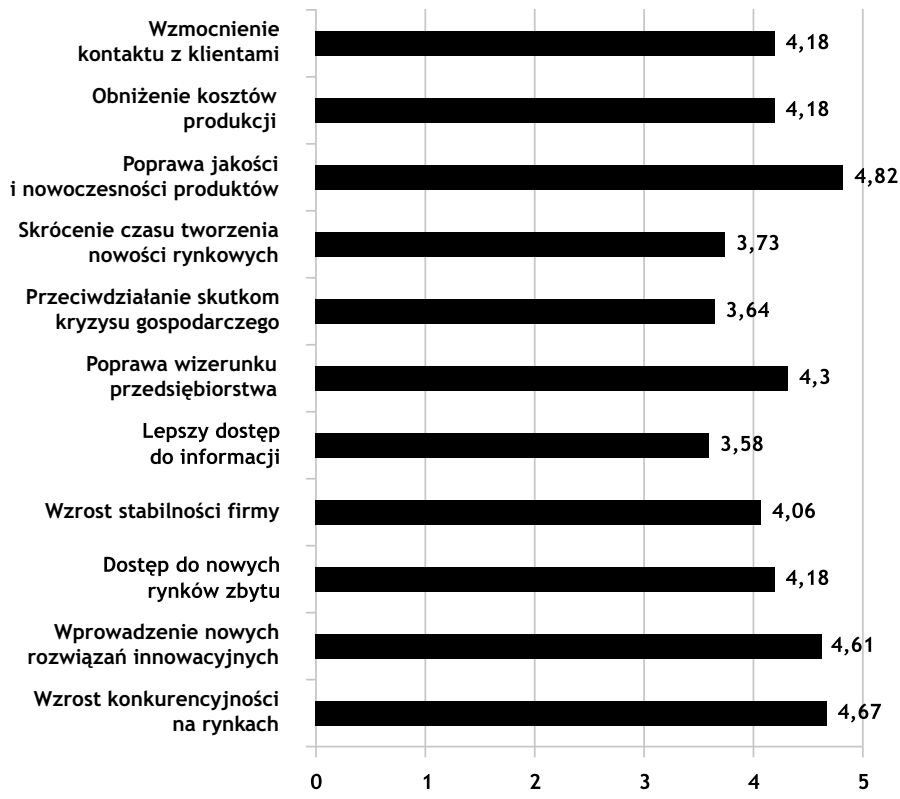

Rys. 2. Znaczenie poszczególnych korzyści dla dużych przedsiębiorstw z podjęcia współpracy z MSP - wartość średnia, $n=33$

Źródto: opracowanie wtasne

Analiza wyników badania w obszarze uzyskanych korzyści ze współpracy z MSP wskazuje, iż największym profitem jest poprawa jakości i nowoczesności produktów dużych przedsiębiorstw (rys. 2). Istotne są także wzrost konkurencyjności oraz wprowadzanie nowych rozwiązań innowacyjnych do przedsiębiorstw. Natomiast wśród najmniej znaczących korzyści wskazano lepszy dostęp do informacji, przeciwdziałanie skutkom kryzysu oraz możliwość skrócenia czasu procesu kreowania innowacji. Szczególnie zaskakującym wynikiem jest stosunkowo niska wartość znaczenia tej ostatniej determinanty, czyli skrócenia czasu projektowania nowości rynkowych. Gdyż wydaje się, iż ta cecha jest ściśle związana z możliwością monopolizacji określonego segmentu rynku dla innowacji oraz zwiększenia przewagi konkurencyjnej. Wyjaśnienie tego zjawiska wymaga przeprowadzenia dalszych pogłębionych badań, być może w formie wywiadów osobistych lub badań fokusowych.

Innym obszarem badania była identyfikacja i znaczenie oczekiwań MSP w stosunku do dużych przedsiębiorstw w kontekście współpracy wdrożeniowej innowacji. Mankamentem tego pytania była subiektywność odpowiedzi, zdecydowanie bardziej wiarygodne informacje uzyskano by przy badaniu MSP. Jednak identyfikacja oczekiwań w tym aspekcie wydaje się interesującym obszarem oraz może być przydatna do analizy porównawczej z danymi uzyskanymi w innych badaniach, gdzie podmiotem były jednostki MSP. Według menedżerów dużych przedsiębiorstw, największe znaczenie dla MSP miała solidność i uczciwość w kontaktach partnerskich (rys. 3). Ta cecha jest szczególnie istotna przy nieformalnych umowach na zasadach luźnej kooperacji, gdzie zaufanie umożliwia 


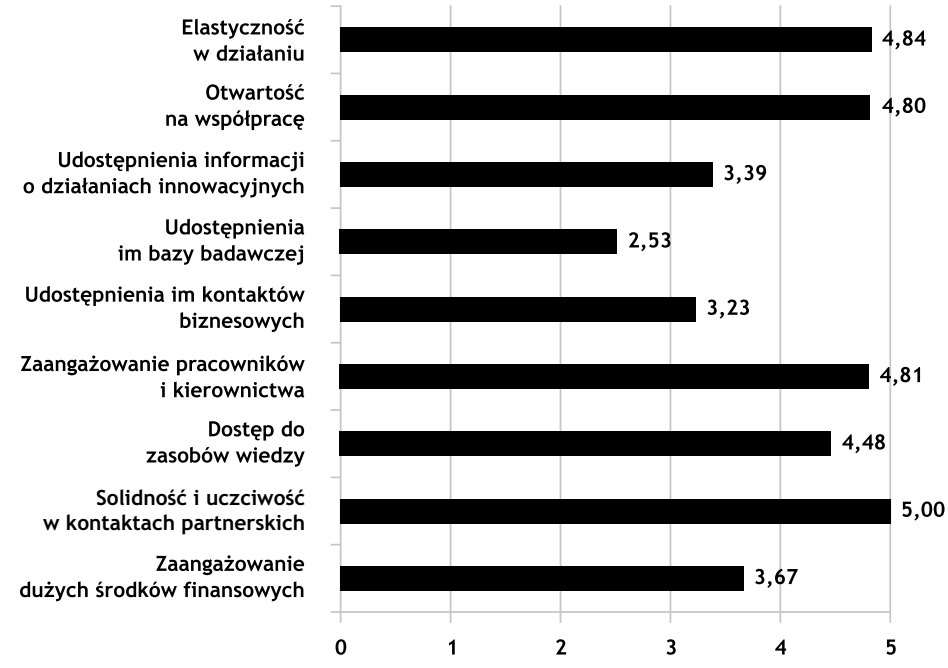

Rys. 3. Znaczenie poszczególnych oczekiwań MSP ze wspótpracy w opinii dużych przedsiębiorstw - wartość średnia, $n=33$

Źródło: opracowanie wtasne

podejmowanie wspólnych decyzji, tworzy atmosferę otwartości i przejrzystości, usprawnia komunikację oraz motywuje i łączy ludzi (Szymańska, 2011, s. 452). Często widoczna jest zależność, gdzie współpraca ulega dalszemu wzmocnieniu, jeśli zwiększa wzajemne zaufanie partnerów biznesowych i odwrotnie - wzrost wzajemnego zaufania w przedsiębiorstwach przyspiesza generowanie wiedzy i wzmacnia więzi (Olesiński, 2016, s. 23; Wasiluk, 2013, s. 54-55).

Niewiele mniejsze znaczenie miały: elastyczność w działaniu, otwartość na współpracę oraz zaangażowanie pracowników i kierownictwa. Uzyskane wyniki pokrywają się $\mathrm{z}$ innymi badaniami, wskazującymi zaangażowanie pracowników jako jeden $\mathrm{z}$ istotnych czynników sukcesu przedsiębiorstw (Jakubow, 2005, s. 112). Zaś aby przedsiębiorstwo mogło wprowadzać innowacje i lepiej dostosowywać się do potrzeb rynkowych, konieczna jest jego otwartość na zmiany (Mądra, 2013, s. 22). A kadra kierownicza organizacji powinna być świadoma potencjału i możliwości wdrożenia innowacji oraz odpowiednio reagować na zaistniałe zmiany. Jednakże współcześni kierownicy dalecy są od „ideału” (Jędrzejczyk, 2016, s. 47).

Najmniejsze oczekiwania MSP w stosunku do dużych podmiotów wykazywały w obszarze udostępniania baz badawczych, np. laboratoriów i innych obiektów i pomieszczeń naukowych, mimo iż przełomowe innowacje (breakthrough innovation) w dobie globalizacji i powszechnej informatyzacji pojawiają się przeważnie dzięki wykorzystywaniu przez przedsiębiorstwa wyników badań naukowych, realizowanych w laboratoriach czy obiektach doświadczalnych (Badowska, 2014, s. 37). Innym wnioskiem jest niezbyt duże znaczenie dla MSP takich elementów, jak kontakty biznesowe oraz ogólne działania proinnowacyjne dużych przedsiębiorstw. Być może wynika to $\mathrm{z}$ faktu, iż te obszary stanowią bardzo cenne źródło konkurencyjności i menedżerowie sektora MSP mają świadomość niechęci dzielenia się tymi zasobami, nawet w relacjach partnerskich.
Ostatni badany obszar współpracy dużych przedsiębiorstw z sektorem MSP obejmował aspekt występujących barier i problemów. Porównując ogólne średnie uzyskane wyniki znaczenia dla każdej ze zidentyfikowanych barier z wynikami z poprzednich pytań, należy zauważyć zdecydowanie mniejsze znacznie aspektu barier w działalności wdrożeniowej innowacji (rys. 4). Największym problemem jest brak skłonności MSP do podejmowania ryzyka wdrożenia innowacji. Ryzyko innowacyjne jest kompilacją ryzyka ekonomicznego i technicznego, można je podzielić na obszar finansowy, projektowy oraz właścicieli. Składowe te korelują z klasycznymi własnościami innowacji, czyli: dużymi kosztami projektowania i wdrożenia oraz długim horyzontem czasowym (Deptuła, Knosala, 2017, s. 11). Kolejnymi istotnymi przeszkodami, jakie wskazali respondenci w obszarze współpracy wdrożeniowej innowacji, były brak odpowiednich zasobów oraz wysokie koszty współpracy. Różnego rodzaju kwestie finansowe utrudniają podjęcie współpracy, która to determinanta jest szczególnie istotna dla sektora MSP. Wśród kosztów partnerstwa w obszarze innowacji należy podkreślić wysokie koszty prac badawczo-rozwojowych, technologii oraz samego procesu wdrożenia i dyfuzji innowacji, ponadto ograniczone środki własne MSP i trudności w pozyskaniu zewnętrznego finansowania powodują wzrost znaczenia tej bariery (Poznańska, 2016, s. 154).

W grupie pozostałych barier warto wymienić: brak kwalifikacji właścicieli i menedżerów, wysokie koszty współpracy, brak zaangażowania ze strony MSP oraz ogólne problemy komunikacyjne na drodze duże przedsiębiorstwo - sektor MSP. Natomiast jako mniej znaczące bariery wskazano brak strategii rozwoju, niewystarczającą otwartość na otoczenie oraz odmienne oczekiwania sektora MSP i dużych przedsiębiorstw. Samo współdziałanie oznacza związek pomiędzy organizacjami, które dążą do osiągnięcia w tym samym czasie wspólnego celu bądź uniemożliwienia osiągnięcia celów rozbieżnych. Cele partnerów nie mogą być rozbieżne z celami pozostałych członków grupy, do której należą (Penc, 2011, s. 139). 


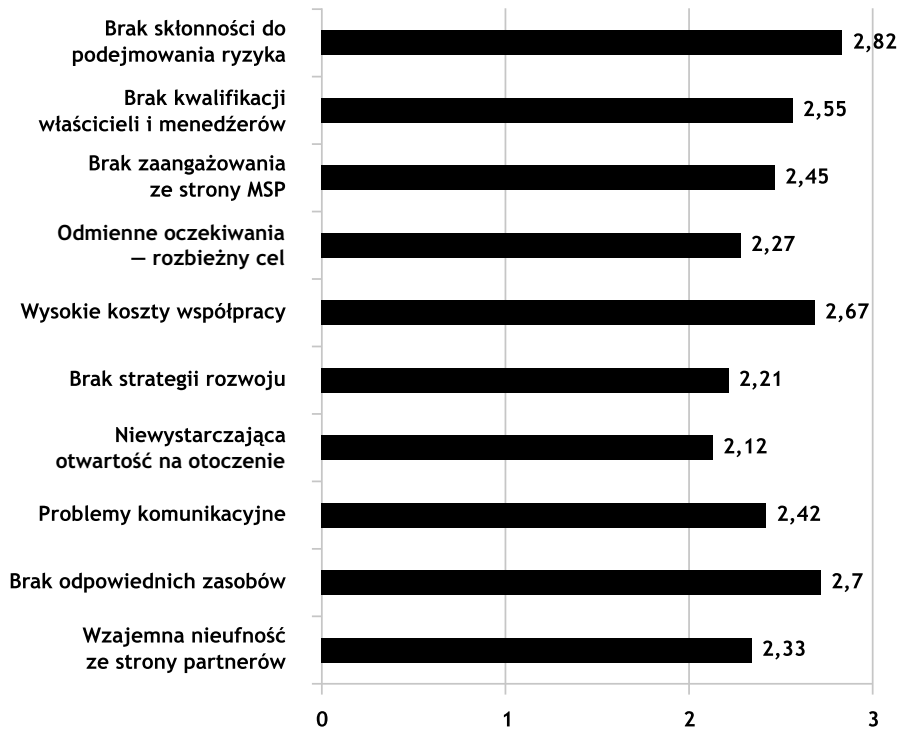

Rys. 4. Znaczenie barier podczas podjęcia współpracy dużych przedsiębiorstw z MSP, $\mathrm{n}=33$

Źródto: opracowanie wtasne

A brak otwartości na otoczenie w kontekście wdrażania innowacji jest sprzeczne ze współczesnymi modelami innowacji, zarówno symultanicznym, konceptualnym, jak i interakcyjnym (Blażlak, Owczarek, 2013, s. 22-30), a szczególnie koncepcją otwartych innowacji (Stanisławski, Lisowska, 2014, s. 249).

Uzyskane wyniki w większości pokrywają się z innymi opracowaniami dotyczącymi ograniczeń wdrażania innowacji, gdzie najistotniejszymi zidentyfikowanymi problemami była biurokracja związana z pozyskiwaniem funduszy, brak własnych zasobów, zbyt długi czas wdrażania innowacji oraz nieufność (Cyran, 2016, s. 205).

\section{Podsumowanie}

$\mathbf{P}$ roblematyka dotycząca współpracy przedsiębiorstw w zakresie innowacji nabiera współcześnie szczególnej wartości. Podmioty, które chcą być konkurencyjne na rynku, muszą kreować oraz wdrażać innowacje. Wysoka aktywność innowacyjna zależy od możliwości danego przedsiębiorstwa, branży oraz wielu czynników zewnętrznych. Jednak współpraca, szczególnie sektora MSP z dużymi przedsiębiorstwami, zwiększa szanse na końcowy sukces innowacji.

Z przeprowadzonych badań i analizy wyników można wnioskować, iż analizowane przedsiębiorstwa chętnie podejmują współpracę $\mathrm{w}$ zakresie wdrażania innowacji. Największym motywatorem jest możliwość stworzenia nowych produktów. Wśród wielu korzyści takiego partnerstwa największe znaczenie dla dużych podmiotów ma poprawa jakości i nowoczesności swojej oferty produktowej. Zauważane są także wzrost konkurencyjności na rynkach oraz możliwość wprowadzenia nowych rozwiązań o charakterze innowacyjnym. Nawiązując współpracę, sektor MSP oczekuje od dużych podmiotów solidności i uczciwości w kontaktach partnerskich, a także elastyczności w działaniu i otwartości na współpracę. Mimo iż występujące bariery takiej współpracy mają stosunkowo małe znaczenie, to duże podmioty wskazują, iż największą przeszkodą jest brak skłonności przedsiębiorstw MSP do podejmowania ryzyka oraz brak odpowiednich zasobów.

Uwzględniając kluczowe znaczenie innowacji w kształtowaniu pozycji konkurencyjnej dzisiejszych przedsiębiorstw oraz ogrom korzyści wynikających ze współpracy biznesowej, wydaje się konieczne podjęcie wspólnych działań mających na celu osiągnięcie sukcesu we wdrażaniu innowacji. Uzyskane wyniki potwierdzają, że partnerstwo pomiędzy firmami jest ważnym obszarem dla innowacji, dostarcza pomysłów i motywuje do działań dynamizujących rozwój innowacyjny, zwłaszcza w przypadku współpracy sektora MSP z dużymi podmiotami. Pozwala na dostęp do ich zasobów, skraca czas procesu innowacji oraz zwiększa szanse na końcowy sukces wdrożenia. Analizując wyniki, należy pamiętać o ograniczeniach przeprowadzonego badania, metody CATI i CAWI pozwalają uzyskać dane subiektywne, a próba badawcza w postaci 33 dużych przedsiębiorstw nie jest reprezentatywna. Dalsze badania w obszarze współpracy na płaszczyźnie wdrażania innowacji będą dotyczyły formy i częstości kontaktów partnerskich oraz badania $\mathrm{w}$ analizowanym obszarze podmiotów MSP.

\section{dr hab. inż. Grzegorz Szymański, prof. uczelni Politechnika Łódzka \\ Wydział Zarządzania i Inżynierii Produkcji \\ ORCID: 0000-0003-3179-1805 \\ e-mail: grzegorz.szymanski@p.lodz.pl}

\section{Przypis}

1) Autor celowo zastosował uproszczenie i w artykule będzie używał określenia duże przedsiębiorstwo, mając na myśli przedsiębiorstwo niespełniające kryteriów MSP w rozumieniu 
Załącznika 1 do Rozporządzenia Komisji WE nr 651/2014 z dnia 17 czerwca 2014 r., uznające niektóre rodzaje pomocy za zgodne z rynkiem wewnętrznym w zastosowaniu art. 107 i 108 Traktatu (Dz.Urz. UE L 187 z 26.06.2014 r.).

\section{Bibliografia}

[1] Badowska S. (2014), Wspótpraca przedsiębiorstw z jednostkami badawczo-rozwojowymi $w$ tworzeniu i rozwoju innowacji produktowych $w$ sektorze spożywczym $w$ województwie pomorskim, „Zarządzanie i Finanse”, T. 12, Nr 2, s. $35-53$.

[2] Blażlak R., Owczarek K. (2013), Modele transferu technologii, Wydawnictwo Politechniki Łódzkiej, Łódź.

[3] Blażlak R., Pomykalski A. (2015), Regionalne uwarunkowania transferu technologii, „Przegląd Organizacji”, Nr 1, s. 11-17.

[4] Cyran K. (2016), Ograniczenia wdrażania działań innowacyjnych $w$ sektorze małych $i$ średnich przedsiębiorstw, Studia Ekonomiczne. Zeszyty Naukowe Uniwersytetu Ekonomicznego w Katowicach, Nr 276, s. 197-209.

[5] Deptuła A.M., Knosala R. (2017), Innowacje i ich ryzyko - czy warto próbować? „Zarządzanie Przedsiębiorstwem”, Nr 4, s. 10-17.

[6] Forsman H., Rantanen H. (2011), Small Manufacturing and Service Enterprises as Innovators. A Comparison by Size, „European Journal of Innovation Management”, Vol. 14, No. 1, pp. 27-50.

[7] Fritsch D.J., Storey M. (2014). Entrepreneurship in a Regional Context: Historical Roots, Recent Developments and Future Challenges, „Regional Studies”, Vol. 48, No. 6, s. 939-954.

[8] Jagoda-Sobalak D., Łapuńka I., Marek-Kołodziej K. (2017), Projektowanie i wdrażanie rozwiazań innowacyjnych, „Organizacja i Zarządzanie”, Nr 114, s. 155-165.

[9] Jakubow L. (2005), Źródła sukcesów małych i średnich przedsiębiorstw w Polsce, Prace i Materiały Wydziału Zarządzania Uniwersytetu Gdańskiego, Nr 5, s. 298-301.

[10] Jasiński A.H. (2018), Innowacyjność polskiej gospodarki a fundusze unijne: czy POIG coś pomógt? Studia i Prace Wydziału Nauk Ekonomicznych i Zarządzania, Nr 52/2, s. 225-240.

[11] Jędrzejczyk W. (2016), Dysfunkcje pracy kierowniczej w organizacjach, „Przegląd Organizacji”, Nr 12, s. 42-48.

[12] Kisielnicki J. (2016), Innowacyjność gospodarki polskiej na tle wybranych krajów Unii Europejskiej i świata, Studia Ekonomiczne. Zeszyty Naukowe Uniwersytetu Ekonomicznego w Katowicach, Nr 281, s. 67-79.

[13] Kłopotek A. (2005), Źródła finansowania wdrożeń innowacji w przedsiębiorstwach $w$ Polsce, [w:] A. Sosnowska i in. (red.), Jak wdrażać innowacje technologiczne $w$ firmie poradnik dla przedsiębiorców, Polska Agencja Rozwoju Przedsiębiorczości, Warszawa, s. 86-139.

[14] Kotler Ph. (1994), Marketing. Analiza, planowanie, wdrożenie $i$ kontrola, Gebethner i Spółka, Warszawa.

[15] Mazur-Wierzbicka E. (2015), Działalność innowacyjna przedsiębiorstw w Polsce, Zeszyty Naukowe Małopolskiej Wyższej Szkoły Ekonomicznej w Tarnowie, T. 26, Nr 1, s. 97-109.
[16] Mądra J. (2013), Specyfika innowacyjności w przedsiębiorstwach $z$ sektora MŚP, „Rynek - Społeczeństwo - Kultura”, Nr 1(5), s. 21-26.

[17] Olesiński Z. (2016), Współpraca małych i średnich przedsiębiorstw jako sposób ich rozwoju, Zeszyty Naukowe Uczelni Vistula, Nr 51(6), s. 18-32.

[18] Oslo Manual, Guidelines for Collecting and Interpreting Innovation Data, 3rd Edition, OECD Publishing, 2005, pp. 10-25.

[19] Penc J. (2011), Zachowania organizacyjne w przedsiębiorstwie: Kreowanie twórczego nastawienia i aspiracji, Oficyna a Wolters Kluwer business, Warszawa.

[20] Pomykalski A. (1997), Innowacje, Wydawnictwo Politechniki Łódzkiej, Łódź.

[21] Poznańska K. (2016), Wspótpraca małych i średnich przedsiębiorstw $z$ podmiotami zewnętrznymi $w$ zakresie innowacyjności, Studia Ekonomiczne. Zeszyty Naukowe Uniwersytetu Ekonomicznego w Katowicach, Nr 280, s. 143-156.

[22] Ratajczak-Mrozek M. (2011), Motywy wspótpracy małych i średnich przedsiębiorstw - wyniki badań, [w:] A. Adamik (red.), Kształtowanie konkurencyjności i przewagi konkurencyjnej małych i średnich przedsiębiorstw, Wydawnictwo C.H. Beck, Warszawa, s. 37-41.

[23] Ritter T., Wilkinson I., Johnston W.J. (2002), Measuring Network Competence: Some International Evidence, „Journal of Business \& Industrial Marketing", Vol. 17, No. 2/3, pp. 119-138.

[24] Schumpeter J. (1960), Teoria rozwoju gospodarczego, PWN, Warszawa.

[25] Skrzypek A. (2018), Open Innovation in Business Models, „Annales H - Oeconomia”, T. 52, Nr 6, s. 98-109.

[26] Sopińska A. (2018), Kreatywność a innowacyjność organizacji. Otwarte innowacje jako przejaw wspótkreatywności, „Studia i Prace Kolegium Zarządzania i Finansów”, Nr 161, s. 11-27.

[27] Stanisławski R. (2014), Open innovation wśród małych $i$ średnich przedsiębiorstw jako instrument ksztattowania przewagi konkurencyjnej, „Economics and Management”, Nr 2, s. 169-184.

[28] Stanisławski R., Lisowska R. (2014), Skłonność do Open Innovation warunkiem rozwoju MSP $w$ kontekście wspótpracy z otoczeniem, [w:] A. Stabryła, S. Wawak (red.) Problemy zarzadzania organizacjami $w$ społeczeństwie informacyjnym, Mfiles.pl, Kraków, s. 247-257.

[29] Sudolska A. (2009), Skłonność przedsiębiorstw sektora MSP do podejmowania kooperacji o charakterze proinnowacyjnym, „Ekonomiczne Problemy Usług”, Nr 34, s. 225-232.

[30] Szymańska K. (2011), Zaufanie, wspótpraca i partnerstwo $w$ procesie kształtowania innowacyjności małych firm, „Ekonomiczne Problemy Usług", Nr 63, s. 449-457.

[31] Szymański G., Stanisławski R. (2018), Motivators of Open Innovation Use in Micro, Small And Medium-Sized Enterprises, „Journal of Fundamental and Applied Sciences”, Vol. 10, No. 3S, s. 243-256.

[32] Wasiluk A. (2013), Zaufanie i wspótpraca pomiędzy przedsiębiorstwami $w$ perspektywie budowy $i$ rozwoju struktur klastrowych, „Ekonomia i Zarządzanie”, Nr 4, s. 49-66.

[33] Wiśniewska J., Janasz K. (2018), Działalność innowacyjna przedsiębiorstw w Polsce, [w:] R. Knosala (red.), Innowacje 
$w$ zarzadzaniu i inżynierii produkcji, Oficyna Wydawnicza Polskiego Towarzystwa Zarządzania Produkcją, Opole, s. 139-150.

[34] Załącznik 1 do Rozporządzenia Komisji (WE) nr 800/2008 z dnia 6 sierpnia 2008 r. uznającego niektóre rodzaje pomocy za zgodne ze wspólnym rynkiem w zastosowaniu art. 87 i 88 Traktatu (ogólne rozporządzenie w sprawie wyłączeń blokowych), Dz.U. WE L 214/38, 9.8.2008.

[35] Zastępowski M. (2018), Audyt procesu zarządzania innowacjami kujawsko-pomorskich mikroprzedsiębiorstw, Studia Ekonomiczne. Zeszyty Naukowe Uniwersytetu Ekonomicznego w Katowicach, Nr 359, s. 8-17.

\section{Cooperation of Large Enterprises with SMES in the Framework of Implementing Innovations}

\section{Summary}

Nowadays, if a company strives to maintain a high position on the market, it is advisable to create innovations in terms of both optimisation of production processes, organisation and increase of competitiveness. Cooperation with other enterprises in the context of innovative development is of key importance for the final success. The aim of this study is to identify the significance of selected elements of cooperation between large enterprises and the SME sector in the area of implementing innovations in Poland. The research involved 33 large companies located in Poland. The analysis of the results of the conducted research shows that the analysed enterprises are willing to cooperate in the field of innovation implementation. The biggest motivator is the opportunity to create new products. Among the many benefits of the partnership, the improvement in the quality and modernity of their product offer is of the greatest importance to large entities. While establishing the cooperation, the SME sector expects from large entities, reliability and integrity in partner relations as well as flexibility in operation and openness to cooperation.

\section{Keywords}

implementation of innovations, innovativeness of Polish enterprises, business cooperation 